\title{
FAKTORI KOJI UTIČU NA BRZINU NOVCA U OPTICAJU
}

\section{Đorđe Dubovina}

Singidunum Univerzitet, Beograd, Srbija

\begin{abstract}
Apstrakt:
Predmet istraživanja ovog rada je brzina opticaja novca. Oslanjajući se na ekonomske teorije, u ovom radu je predočeno kako se nekada gledalo na brzinu opticaja novca. Takođe, prikazani su faktori koji utiču na brzinu opticaja novca u savremenim ekonomskim uslovima, kao i uticaj elektornskog novca na monetarne agregate i brzinu opticaja novca. U radu je ukazano na novine koje je elektronski novac doneo u sprovođenju monetarne politike, kao i na nedostatke elektronskog novca. U praktičnom delu obuhvaćeno je nekoliko godina uoči i tokom ekonomske krize 2008. godine i prikazano je kako promena uslova utiče na brzinu opticaja novca.
\end{abstract}

Ključne reči:

elektronski novac, ekonomska kriza, monetarni agregati, monetarna politika ekonomske teorije.

\section{UVOD}

U radu ćemo pokušati da objasnimo kako su ekonomske teorije tumačile brzinu opticaja novca, a kako se ona tumači danas u savremenim uslovima, i kojim se faktorima pridaje najveći značaj. Objasnićemo šta je elektronski novac, koje su njegove prednosti i nedostaci, kako utiče na monetarne agregate i brzinu opticaja novca. U praktičnom delu rada istražićemo: kamatne stope, zarade, zaposlenost, štednju stanovništva, monetarne agregate i devizni kurs, kako bismo videli kako promena parametara utiče na brzinu novca u opticaju.

\section{KAKO SE MERILA BRZINA OPTICAJA NOVCA?}

Efekat koji novčana masa ima u privredi zavisi od količine novca u opticaju i brzine opticaja novca. Brzina opticaja novca pokazuje koliko puta jedna novčana jedinica učestvuje u obavljanju transakcija u određenom vremenskom periodu. U monetarnoj teoriji, brzina opticaja novca predstavlja izuzetno važnu kategoriju, jer od nje zavisi kolika će količina novca biti potrebna u opticaju, da bi se robno-novčane transakcije nesmetano odvijale. Empirijska istraživanja novca su pokazala da je brzina opticaja novca privrednog sektora veća nego kod sektora stanovništva.

U ovom radu ćemo se osvrnuti na analize Kunta Viksela, takozvanu Austrijsku školu Fridriha fon Hajeka, Fišerov i Sejov zakon tržišta, kako bismo objasnili teorije koje određuju brzinu novčanog opticaja. ${ }^{1}$

Viksel je nastojao da razvije kvantitativnu teoriju novca, koja ne bi bila zamena za postojeću kvantitativnu teoriju novca, već njena razrada. Viksel je uveo novine u ulozi kreiranja kredita, dok po njegovom mišljenju novac ima pasivnu ulogu u formiranju cena (Wicksell, 1965).

1 Prva generacija Austrijske škole se bavila mikroekonomskim pitanjima, a druga generacija se bavila poslovim ciklusima, problemima novca i metodološkim osnovama ekonomske nauke.
Korespondencija:

Đorđe Dubovina

e-mail:

dordje.dubovina.14@singimail.rs 
Kreiranje kredita se javlja kao aktivan element koji izaziva povećanje cena proizvoda, čija je proizvodnja kreditno finansirana.

U osnovi ove analize je visina tižišne kamatne stope po kojoj komercijalne banke odobravaju kredite. Ako je tržišna kamatna spota niža od prirodne kamatne stope, preduzetnici će biti prinuđeni da povećaju svoje zaduživanje kod banaka, čime će izazvati povećanje cene finalnog proizvoda. Cene će se konstantno povećavati, sve dok postoji razlika između tržišne i prirodne kamatne stope.

Kunt Viksel pretpostavlja da bi uvođenjem zlatnog standarda nestala razlika između ovih kamatnih stopa, jer bi povećanje cena povećalo tražnju za novcem koji ima zlatnu podlogu od države, ali ne i od banaka. Banke bi tada smanjile rezerve i povećale kamatnu stopu. Važno je istaći da se u Vikslovoj analizi sa povećanjem količine novca ne povećava inflacija, već je razlog za povećanje inflacije nepodudaranja tržišne i prirodne kamatne stope.

Nameće se pitanje: kako se formira prirodna kamatna stopa? Prirodna kamatna stopa je određena realnim nemonetarnim faktorima. Otuda ni kretanje nivoa cena nije potpuno monetarni fenomen koji je vezan za monetarni sistem.

Povećana novčana masa će izazvati privremeni pad kamatne stope, koji će biti prisutan sve dok rast cena neutrališe dodatnu ponudu novca i vrati kamatnu stopu na prethodni nivo. Viskel prirodnu kamatnu stopu definiše na tri načina (Parašević, 2003):

1. Kao stopu koja se formira pri ravnoteži štednje i investicija u ekonomiji. $^{2}$

2. Marginalni proizvod kapitala - prirodna stopa predstavlja prinos kapitala, odnosno realnu profitnu stopu.

3. Stabilnost cena će se obezbediti jednakošću tržišne i prirodne kamatne stope, ali pri tom neće postojati kreiranje kredita.

To nameće sledaća pitanja:

1. Da li u rastućoj ekonomiji nivo cena može da ostane stabilan, ako ne postoji kreiranje kredita?

2. Kako dolazi do monetarne ravnoteže?

3. Da li će štednja i investicije, kao pozitivne veličine u rastućoj ekonomiji, biti izjednačene pri kamatnoj stopi jednakoj marginalnom proizvodu po jedinici kapitala?

Viksel ističe da monetarna ravnoteža mora da ispuni tri uslova:

1. Jednakost prirodne kamatne stope (r) i normalne kamatne stope (n).

2. Jednakost tržišne kamatne stope (i) i prirodne kamatne stope (r), pri čemu prirodna kamatna stopa određuje obim investicija, a tržišna kamatna stopa nivo štednje.

2 Pretpostavka je da se privreda bazira na trampi, odnosno da novac ne postoji.
3. Pri jednakosti prirodne i tržišne kamatne stope, agregatna tražnja $\left(\mathrm{Y}^{\mathrm{d}}\right)$ je jednaka agregatnoj ponudi $\left(\mathrm{Y}^{\mathrm{s}}\right)$, a opšti nivo cena $(\mathrm{P})$ je stabilan.

Kumulativni proces otpočinje, kada je prirodna kamatna stopa (r) viša od tržišne kamatne stope (i), a to znači da je marginalni proizvod kapitala viši od troška kapitala. Vikselova analiza kumulativnog procesa se uklapa u tadašnje razumevanje kretanja visine cena. On tvrdi da su promene nivoa cena zasnovane na činjenici da se cene, u dužem vremenskom periodu, kreću u tom pravcu. Osnovni razlog za pomeranje nivoa cena je neravnoteža između bankarske kamatne stope na nivou koji je različit od nivoa prirodne kamatne stope (Parašević, 2003).

Postoje dva razloga koji dovode do okončanja kumulativnog procesa i ponovnog uravnotežanja tržišta dobara, gde su investicije jednake štednji ( $\mathrm{I}=\mathrm{S})$. Zašto kumulativni proces nije beskonačan?

1. Vremenom će se smanjiti rezerve banke (u gotovini ili zlatu), koje su omogućavale veštačko održavanje bankarske kamatne stope na nižem nivou od prirodne kamatne stope. Čim dođe do toga, banke će morati da obustave ili smanje kreditiranje, što će dovesti do rasta tržišnih kamatnih stopa na odobrene kredite.

2. Samouravnotežavajući mehanizam (koje je uveden nešto kasnije) će uticati na pad prirodne kamatne stope, izazvan inflacijom. Sa inflacijom koja je posledica otpočinjanja kumulativnog procesa, doći će i do rastra troškova angažovanja dodatnog kapitala, odnosno smanjiće se atraktivnost novih investicija. Tako će zbog inflacije doći do pada prirodne kamatne stope, što će izazvati pokretanje samouravnotežujućeg mehanizma u sistemu (Parašević, 2003).

Na osnovu kumulativnog procesa može se uočiti da u kratkom roku ne postoji neutralnost novca, ali dugoročno se održava postavka kvantitativne teorija novčane mase i opšteg nivoa cena, odnosno inflacije.

Fridrih fon Hajek je značajno doprineo razvoju teorije opšte ravnoteže. On tvrdi da u privredama koje su predmet monetarnih uznemiravanja, privredni ciklusi mogu da se pojave zato što cene pružaju pogrešne signale.

Hajek prirodnu kamatnu stopu definiše kao stopu pri kojoj se izjednačavaju želje investitora da ulažu i želje ekonomskih subjekata da štede. Ako stvarna kamatna stopa ne odgovara prirodnoj, na makro nivou će se pojaviti neravnoteža između želje da se štedi i želje da se investira. Pad kamatne stope ispod nivoa prirodne kamatne stope znači povećano investiranje, ali ono neće biti ispraćeno većom štednjom.

Ekonomska kriza je posledica monetarnog kreiranja kredita bankarskog sistema. Pojavljivanje krize može biti odloženo, ali po cenu povećanja njene oštrine, kada ona nastupi, odnosno ne može biti izbegnuta.

Hajek dokazuje da je rastuća inflacijaneophodan uslov, a ne posledica ekonomske ekspanzije. Jedan od stavova au- 
strijske škole je da pokušaj izbegavanja krize monetarnom ekspanzijom, ne izaziva samo inflaciju, već i rastuću inflaciju ${ }^{3}$.

Teorija koja je kamen temeljac Sejovog zakona tržišta je kvantitativna teorija novca. Ako pozajmimo formulu Irvinga Fišera, proizvod količine novca u opticaju ( $\mathrm{M}$ - gotov novac i depoziti u bankama) sa brzinom opticaja gotovog novca i depozita u bankama (V - koliko brzo novac prelazi iz ruke u ruku u toku određenog vremena) jednak je proizvodu nivoa cena (P) i fizičkog obima transakcija (T) u jednoj ekonomiji $(\mathrm{MV}=\mathrm{PT})$.

Fišerova pretpostavka je da kratkoročne i dugoročne promene $u$ ponudi novca ne utiču na brzinu opticaja novca $(\mathrm{V})$ i obim transakcija (T). Brzina opticaja novca (V) zavisi od institucionalnih promena kao što su: promene u načinu poslovanja banaka, otkrića u načinu plaćanja, brzina transportne i komunikacione mreže, učestalost i raspored prihoda $i$ rashoda kod trgovca, dužina perioda isplate u odnosu kreditor-dužnik itd.

Takođe, važna pretpostavka modela je da je novac egzogeno determinisan, $\mathrm{tj}$. da ponudu novca određuje centralna banka svojim uticajem na monetarnu bazu. Fišerova pretpostavka da se brzina novca u opticaju (V) sporo menja, što znači da je tražnja za novcem stabilna, omogućava centralnoj banci da vrši uticaj na količinu novca u opticaju (M).

\section{SAVREMENA RAZMATRANJA BRZINE OPTICAJA NOVCA}

Osnova kvantitativne teorije novca je stabilna monetarna potražnja. Što podrazumeva da je brzina opticaja novca (V) stabilna. Kvantitativna teorija novca važi ili ne važi, sa pretpostavkom da je brzina opticaja novca (V) nepromenljiva i stabilna u odnosu na promene u ponudi količine novca. Ako nije tako nema direktne povezanosti u promeni količine novca na izdatke i nivo cena.

Porastom monetarne ponude dolazi do smanjenja brzine opticaja novca. Usled toga će leva strana jednačine biti nepromenjena, pa se neće ništa dogoditi ni sa desnom stranom jednačine, tj. cene i dohodak će biti nepromenjen. ${ }^{4}$

Opšte prihvaćen stav savremene monetarne teorije je da količina novca predstavlja samo jedan od značajnih faktora privrednih kretanja, posebno u uslovima kreditnog novca. U poslednje vreme se sve veća pažnja poklanja pitanju: Kako i kojom brzinom pojedini instrumenti monetarne politike deluju na osnovne privredne makroagregate kao što su: nacionalni dohodak, cene, zaposlenost?

3 Hajek u svojoj analizi nametnute štednje dokazuje da će se u svakoj privredi, u kojoj postoji kreditna ekspanzija, u jednom trenutku dogoditi da banke više neće moći da održavaju stopu kreditne ekspanzije. Zato u rastućim privredama monetarna neutralnost ne zahteva stabilne cene,već pad opšteg nivoa cena.

4 Jednačina kvantitativne teorije novca: $\mathrm{MV}=\mathrm{PT}$
Novčana masa je promenljiva i dinamična veličina koja zavisi od sledećih faktora:

1. oscilacija privredne aktivnosti,

2. brzine opticaja novca u privredi.

Brzina opticaja novca je veoma značajna za operativna istraživanja i savremenu teoriju. Brzinu opticaja novca je vrlo teško regulisati. Od brzine opticaja i ukupne količine novca zavisi cena robe.

Prihvatanje teorije o konstantnoj brzini novca u opticaju dobija sve veći značaj, što predstavlja njenu slabost. Baš iz razloga što brzina novca u opticaju ranije nije bila konstantna, nego je bila dosta veća nego što je danas, pa se vremenom snižavala.

Brzina novčanog opticaja je i te kako promenljiva veličina, iako se još uvek posmatra kao stabilna veličina, jer je za njeno istraživanje potrebno utvrditi determinante koje je određuju. Vođenje operativne monetarne politike usporavala bi kontrola različitih ekonometrijskih funkcija i modela, što je vrlo komplikovano, jer postojeća novčana masa treba da bude jednaka tražnji za novcem. Uz pomoć brzine novčanog opticaja proučava se povezanost monetarnog i realnog sektora. Brzina novca u opticaju je složen faktor kretanja i ponašanja količine novca, odnosno novčane mase.

\section{FAKTORI KOJI UTIČU NA BRZINU OPTICAJA NOVCA}

Visoka varijabilnost brzine opticaja novca ukazuje na uticaj određenih egzogenih faktora.

Prikazaćemo nekoliko faktora koji utiču na brzinu opticaja novca:

1. Namenska ograničenja u trošenju raspoloživih sredstava. Svaki oblik institucionalnog ograničavanja tražnje ili raspolaganja novčanim sredstavima, utiče na brzinu novca u opticaju. Veća ograničenja i duže raspolaganje novčanim sredstvma usporava brzinu novčanog opticaja.

2. Tehnika platnog prometa. Ova tehnika je često ograničavajući faktor brzine opticaja novca. Ona određuje maksimalnu brzinu opticaja novca. Što je tehnika savršenija, brzina opticaja novca je bolja, reč je o plaćanjima koja nebankarski transaktori obavljaju preko bankarskog sistema.

3. Decentralizacija ili centralizacija novčanih sredstava. Veća centralizacija novčanih sredstava i centralizovana raspodela nacionalnog dohotka, dovode do povećanja brzine opticaja novca, odnosno do preraspodele novčanih sredstava iz sektora stanovništva u sektor privrede. Suprotno, ako dođe do prelivanja novca iz sektora privrede u sektor stanovništva, dolazi do smanjenja brzine novca u opticaju, ali i do porasta potrebne novčane mase. 
4. Stabilnost privrede. Veća ili manja privredna stabilnost privrede dovodi do povećanja ili smanjenja brzine opticaja novca. Veća inflaciona nestabilnost privrede, vodi bržem oslobađanju novca i samim tim bržem opticaju novca. Brzina neuravnoteženog novca u opticaju se približava maksimalnoj brzini i veća je od brzine potrebne količine novca u opticaju, što dovodi do povećanja neuravnoteženog novca i brzine opticaja ukupne novčane mase.

5. Stepen sigurnosti u pogledu novčanih primanja privrednih subjekata. Ukoliko privredni subjekt proceni da postoji velika privredna sigurnost u prilivu poslovnih sredstava i ostvarivanju dohotka, onda će zadržati manja novčana sredstva kao sredstva likvidnosti, jer povećavaju tražnju. Sve to utiče na ubrzanje novčanog opticaja.

6. Psihološki faktor. Ovaj faktor je vrlo kompleksan i značajno utiče na brzinu tražnje dohotka, pa samim tim i na brzinu novca u opticaju. Ove faktore je vrlo teško odrediti i uključiti u program monetarne politike.

7. Frekvencija plaćanja vezana za raspodelu bruto domaćeg proizvoda. Reč je o društveno određenim intervalima u kojima se mora vršiti obračun $i$ isplata dohotka, doprinosa, poreza itd. Ona može delovati pozitivno i negativno. Ukoliko dođe do skraćivanja intervala isplate dohotka i drugih zahtevanja iz dohotka, doći će do pozitivnog delovanja i obratno (Hadžić i Barjaktarović, 2015).

8. Politička stabilnost. U periodu političke nestabilnosti dolazi do povećanja brzine novca u opticaju i obratno.

9. Bankarski krediti. Dugoročni (investicioni) krediti usporavaju brzinu opticaja novca, a kratkoročni krediti ubrzavaju brzinu opticaja novca, jer je potrebno manje vremena da se "obrne" novac i vrati kredit.

Brojni faktori direktno ili indirektno deluju na opticaj novca: kamatna stopa, promena očekivane stope inflacije, promene u strukturi proizvodnje i raspodeli dohotka, struktura stanovništva (seosko - gradsko), uvođenje novih supstituta novca i ostali.

Navedeni su samo osnovni faktori koji utiču na brzinu novca u opticaju, a preko brzine opticaja novcautiču na optimalnu novčanu masu. Postoje i mnogi drugi faktori, ali oni deluju u sklopu privrednog rasta zemlje.

Među faktorima koji neposredno deluju na brzinu novčanog opticaja izdvojićemo:

- Kompenzacione aranžmane koji regulišu plaćanja, često smanjuju tražnju gotovog novca i obim bankarskih kredita.

- Cilj razvojnih mera je da smanje iznos sredstava potrebnih za podmirivanje plaćanja od strane privrednih jedinica.
- Sklonost ka investiranju, uz držanje minimalnih gotovinskih salda privrednih subjekata u našoj privredi.

- Smanjenje tražnje gotovog novca od sektora stanovništva.

Ovi faktori utiču na dugoročno ponašanje brzine opticaja novca. Problem istraživanja determinanti brzine novčanog opticaja je kompleksan, jer se uticaj navedenih faktora u određenom vremenskom intervalu može videti kao:

- istovremeno delovanje,

- suprotno delovanje i poništavanje,

- delimično - istovremeno i delimično - suprotno.

\section{UTICAJ ELEKTRONSKOG NOVCA NA BRZINU NOVČANOG OPTICAJA}

U ovom delu rada pokušaćemo da objasnimo kako je pojava elektronskog novca uticala na monetarnu politiku i brzinu novčanog opticaja; šta se događa sa monetarnim agregatima; i kako centralna banka kontroliše e-novac.

Usled razvoja e-bankarstva dolazi do razvoja e-novca. Elektronski novac je prvi put predstavljen 1994. godine i ceo taj koncept se još uvek nalazi u fazi razvoja. Osnovna pretpostavka tj. hipoteza je: koliko će za centralnu banku biti otežana kontrola monetarnih agregata, ako je elektronski novac prihvaćen kao legitimno sredstvo plaćanja?

Monetarni sistem se sastoji od gotovinskog i bezgotovinskog sistema plaćanja, koji zajedno čine komplementarni platni sistem. Gotovinski sistem plaćanja se zasniva na upotrebi gotovine za plaćanje robe i usluga. Sistem bezgotovinskog plaćanja čini: elektronski novac i plaćanja zasnovana na papiru.

Još uvek je teško dati tačnu definiciju elektronskog novca, pošto se promene u ovoj sferi odvijaju prebrzo. Evropska centralna banka (ECB) je elektronski novac definisala kao monetarnu vrednost sačuvanu na tehničkom uređaju, pri čemu ova vrednost može biti upotrebljena u plaćanjima za veliki broj roba i usluga. Pored ove definicije treba pomenuti i definiciju Federal Services Authority, prema kojoj je e-novac monetarna vrednost koja predstavlja elektronski sačuvano potraživanje izdavaoca, potvrđeno za potrebe obavljanja platnog prometa, pri čemu je ta monetarna vrednost prihvaćena za plaćanje u širim okvirima (Sedlarević et al., 2015).

Na osnovu datih definicija može se zaključiti da se konvencionalnim novcem mora kupiti određena količina elektronskog novca. Potrebno je naglasiti da se elektronski novac odnosi samo na višenamenske kreditne kartice.

Elektronski novac egzistira u monetarnom sistemu koji se zasniva na upotrebi papirnog novca. Papirni novac je nastao u monetarnom sistemu zasnovanom na robnom novcu, sa kojim se paralelno razvijao sve dok se nisu razvile karakteristike koje su ga učinile dominantnijim sredstvom plaćanja. Očekuje se da će elektronski novac, vremenom potisnuti papirni, ali da bi se to dogodilo elektronski novac mora da bude jednako koristan kao papirni novac. 
Očigledno je da se elektronski novac razlikuje od tradicionalnog novca. Osnovne funkcije tradicionalnog novca su: sredstvo plaćanja, čuvar vrednosti, obračunska jedinica, sredstvo odloženog plaćanja. Elektronski novac za sada obavlja samo platežnu funkciju, ali očekuje se da će se u budućnosti to promeniti. Elektronski novac ne može imati funkciju čuvara vrednosti iz sledećeg razloga: ako transaktori žele da u svakom trenutku poseduju likvidna sredstva, oni će određeni deo svojih ukupnih sredstava držati u formi gotovog novca. $\mathrm{Na}$ taj način, uzimajući u obzir karakteristike gotovog novca, može se obezbediti likvidnost u svakom trenutku, pošto jednostavno ne postoje troškovi vremena i konverzije gotovog novca u e-novac. Ako bi željenu svotu novca transaktor ipak pretvorio u elektronski novac, ne bi se postigao isti efekat pošto korišćenje elektronskog novca iziskuje određene troškove u pogledu vremena (Sedlarević et al., 2015).

Definicija koju je dala ECB potvrđuje ovo stanovište, prema ECB e-novac predstavlja monetarnu vrednost koja je sačuvana na odgovarajućem uređaju.

Navešćemo još neke razlike između tradicionalnog i elektronskog novca:

1. Gotov novac predstavlja komponentu monetarnih agregata, dok e-novac nije komponenta nijednog obuhvata novčane mase. Iz tog razloga centralne banke nemaju mogućnost kontrolisanja količine elektronskog novca koji se nalazi kod transaktora.

2. E-novac ima status legitimnog sredstva plaćanja za razliku od gotovog novca. Iza gotovog novca stoji država, što nije slučaj sa e-novcem koji koriste samo ekonomije koje su prihvatile razvijene sisteme e-novca.

Kada govorimo o nedostacima elektronskog novca, treba obratiti pažnju na sigurnost čitavog monetarnog sistema, imajući u vidu karakteristike e-novca. U kontrolisanju e-novca značajnu ulogu ima centralna banka. Prilikom inkorporiranja e-novca u platni sistem mora se ukazati na više interesnih grupa koje su zainteresovane za korišćenje e-novca, jer od njih zavisi dalji razvoj. Sa daljim razvojem ovog koncepta javlja se potreba za novim institucionalnim okvirima monetarne politike. Elektronski novac nikako ne sme ugroziti funkcionisanje monetarnog sistema. Vrlo je važno voditi računa da e-novac ne bude podložan prevarama i falsifikovanju. Operativni rizik je povećan, ako je prilikom transakcije moguće koristiti elektronski novac bez dokaza o njegovom korišćenju. Pravo pitanje u vezi sa razvojem e-novca je njegov pravni tretman. Trenutno nijedan oblik e-novca nema status zakonskog sredstva plaćanja. Sa druge strane, država stoji iza papirnog novca pa je on samim tim u široj upotrebi. Da bi se e-novac razvijao u budućnosti, država treba da ga prihvati kao legitimno sredstvo plaćanja. Dok se e-novac ne prihvati kao zakonsko sredstvo plaćanja, ne može se garantovati njegova šira primena. Neophodno je izvršiti reorganizaciju monetarnog sistema, zbog inkorporiranja e-novca u monetarni sistem. Posebnu pažnju treba usmeriti na finansijske institucije koje izdaju elektronski novac.
Podeljena su mišljanja o efektima koje elektronski novac ima na upravljanje monetarnom politikom. Fridman je 1999. godine pokušao da ukaže na probleme koji nastaju prilikom kontrole monetarne politike u ekonomijama koje su prihvatile e-novac. Ponuđena količina novca u monetarnom sistemu koji nije prihvatio e-novac je: monetarna baza (B) i monetarni multiplikator (m) (Friedman, 1999).

$$
\mathrm{M}=\mathrm{B} \times \mathrm{m}
$$

Monetarna baza predstavlja zbir gotovog novca i rezervi bankarskog sistema.

$$
B=G+R
$$

Posmatrajući e-novac kao legitimno sredstvo plaćanja, i njegovim uvođenjem u monetarni sistem, mora doći do promene monetarnih agregata i monetarne baze. Ove promene uslovljavaju nastanak novih problema centralne banke, koji nisu postojali pre pojave e-novca. Pod pretpostavkom da elektronski novac može zameniti gotov novac u opticaju, i kao posledica smanjenja tražnje za gotovim novcem, dolazi do promene monetarnih agregata. Pošto gotov novac ima najveće učešće u M1 agregatu, tu će doći do najvećih promena.

Izdvojićemo nekoliko potencijalnih efekata e-novca na monetarni sistem:

1. promene u monetarnom multiplikatoru,

2. sposobnost centralne banke da sprovodi monetarnu politiku,

3. brz opticaj novca,

4. senjoraža,

5. visina rezervi,

6. uvođenje međunarodne kontrole,

Upotrebom e-novca vrednost multiplikatora se menja, što utiče na efikasnost monetarne politike. Posmatrano sa stanovištva monetarnih agregata, postavlja se pitanje ko je emitent e-novca. Da li je to centralna banka ili neka druga institucija?

U monetarnom sistemu, gde e-novac pripada kao element novčanoj masi, monetarni multiplikator se može definisati na sličan način. Novčani obuhvat M1 ćemo proširiti iznosom e-novca koji koriste transaktori za plaćanje (E). Ukoliko enovac izdaju posebne institucije, on neće biti element monetarne baze. U tom slučaju monetarni multiplikator će biti izražen na sledeći način (Sadlarević et al., 2015):

$$
\mathrm{m}=\frac{\mathrm{G}+\mathrm{D} \times \mathrm{E}}{\mathrm{G} \times \mathrm{R}}
$$

Da li će razvoj novca uticati na efikasnost sprovođenja monetarne politike? Neki misle da centralna banka treba da postane emitent e-novca. U odnosu na druge institucije koje mogu emitovati e-novac, centralna banka ima komparativne 
prednosti, samim tim što predstavlja centralnu monetarnu instituciju. Ova pozicija će centralnoj banci omogućiti da zadrži kontrolu nad monetarnom politikom. Uvođenje elektronskog novca u monetarni sistem odraziće se na brzinu novca u opticaju. Brzina opticaja novca se može izraziti kao multiplikator $\left(\mathrm{m}_{\mathrm{v}}\right)$ koji povezuje ponuđenu količinu novca i nominalni bruto domaći proizvod:

$$
\mathrm{M} \times \mathrm{V}=\mathrm{P} \times \mathrm{Y}
$$

Pojavlje se određeni problem u merenju brzine opticaja novca, zbog toga što nije jednostavno odrediti stvarne tokove plaćanja e-novcem. Izdvojićemo dva potencijalna efekta e-novca koji deluju na brzinu opticaja novca (Sedlarević et al., 2015):

1. Ako pretpostavimo da e-novac legitimno koegzistira sa gotovim novcem, novčana masa M1 će u tom slučaju, pored gotovog novca i depozita po viđenju, obuhvatiti i e-novac. Pod pretpostavkom da neće doći do promene u visini bruto domaćeg proizvoda i cena, brzina opticaja će se smanjiti zbog povećane ponude novca.
2. Drugi potencijalni efekat polazi od pretpostavke da su gotov novac i e-novac supstituti i da e-novac nije element novčane mase. Tada će, uz ostale faktore, doći do smanjenja gotovog novca i povećanja brzine opticaja novca, pošto će transaktori držati manje gotovog novca i povećati broj transakcija.

\section{FAKTORI BRZINE NOVČANOG OPTICAJA U REPUBLICI SRBIJI OD 2006. DO 2015. GODINE}

U praktičnom delu rada ćemo objasniti kako određeni parametri utiču na brzinu novčanog opticaja, i kako su se oni menjali tokom godina.

Kamatne stope centralne banke mogu uticati na kretanje cena akcija i hartija od vrednosti, kao i na kretanje deviznog kursa. Promene kamatnih stopa i cene HOV utiču na kretanje štednje, potrošnje i investicione odluke stanovništva i privrede.

Pod pretpostavkom da su uslovi nepromenjeni, a kamatne stope više, stanovništvo i privreda uzima kredite pod pritiskom, kako bi finansirali potrošnju ili investicije.

Grafikon 1. Kamatne stope NBS

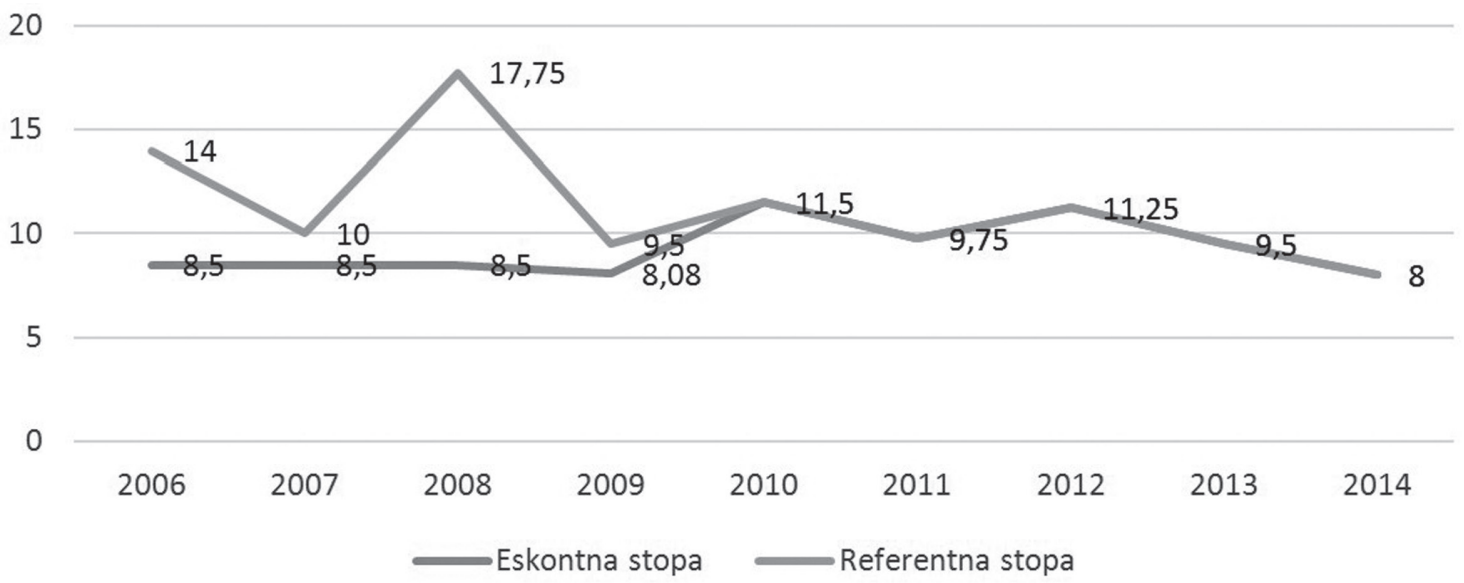

Izvor: NBS, Statistički bilten, jul 2016.

Grafikon 2. Odnos zaposlenosti i štednje u Srbiji

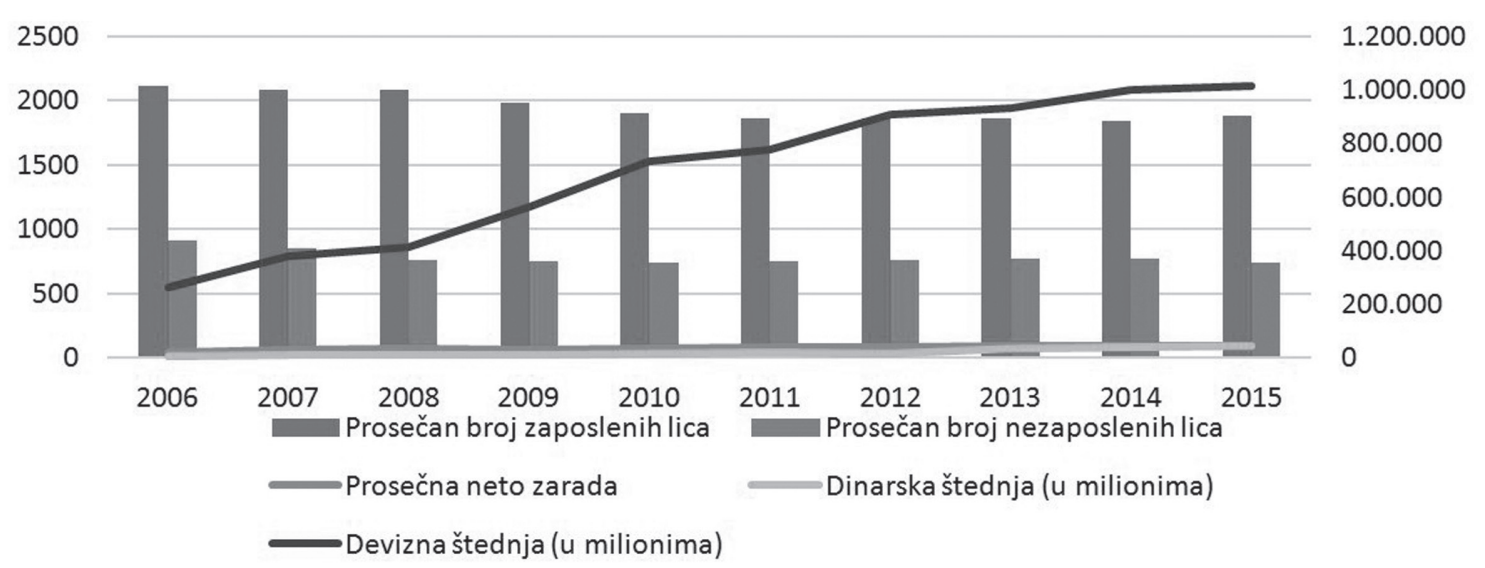


Povećanje referentne kamatne stope centralne banke, dovodi do povećanja kamatnih stopa na kredite i do smanjenja zaduživanja domaćinstva i preduzeća, što će se kasnije negativno odraziti na privredni rast.

Grafikon pokazuje da su kamatne stope izuzetno visoke, ali možemo zaključiti da u zadnje vreme beležepozitivan trend smanjivanja. Od 2008. do 2012. godine zabeležen je rastući trend kamatnih stopa, zbog ekonomske krize, ali i zbog recesije u Srbiji. Referentna kamatna stopa od 4.0\% predstavlja dokaz da se polako izlazi iz ekonomske krize i nestabilnog perioda, ali i da postoji prostor za snižavanje referentne kamatne stope NBS.

Grafikon 2 prikazuje da je prosečan broj zaposlenih bio najviši pre ekonomske krize, a kako je ekonomska kriza odmicala taj broj se postepeno smanjivao. Što se dinarske štednje tiče, ona ima uzlaznu putanju, što znači da stanovništvo vraća poverenje u domaću valutu i banke, ali je to još uvek nisko u poređenju sa deviznom štednjom.

Promene deviznog kursa direktno utiču na cene uvoznih proizvoda i domaće cene. Tokom apresijacije deviznog kursa uvozni proizvodi i sirovine će imati niže cene. Promena deviznog kursa može uticati i na konkurentnost privrede. $\mathrm{U}$ slučaju apresijacije deviznog kursa, domaća privreda će biti manje konkurentna na svetskom tržištu, otuda proizilazi da će se više proizvoda prodavati na domaćem tržištu, i samim tim će se povećati agregatna tražnja.

Prema procenjenom BDP-u za 2016. godinu, brzina opticaja novca, merena novčanom masom $\mathrm{Ml}$, je smanjena u odnosu na prošlu godinu i godine prikazane grafikonom. Mereno novčanom masom M3, brzina opticaja novca je 2016. godine smanjena u odnosu na godine prikazane grafikonom 4 .

Tabela 1. Promene deviznog kursa od 2006. do 2015. godine

\begin{tabular}{ccccccccccc}
\hline & 2006 & 2007 & 2008 & 2009 & 2010 & 2011 & 2012 & 2013 & 2014 & 2015 \\
\hline RSD/USD & 59.98 & 53.73 & 62.90 & 66.73 & 79.28 & 80.87 & 86.18 & 83.13 & 99.46 & 111.125 \\
\hline RSD/EUR & 79.00 & 79.24 & 88.60 & 95.89 & 105.50 & 104.64 & 113.72 & 114.64 & 120.96 & 121.63 \\
\hline
\end{tabular}

Grafikon 3. Kretanje monetarnih agregata u Srbiji

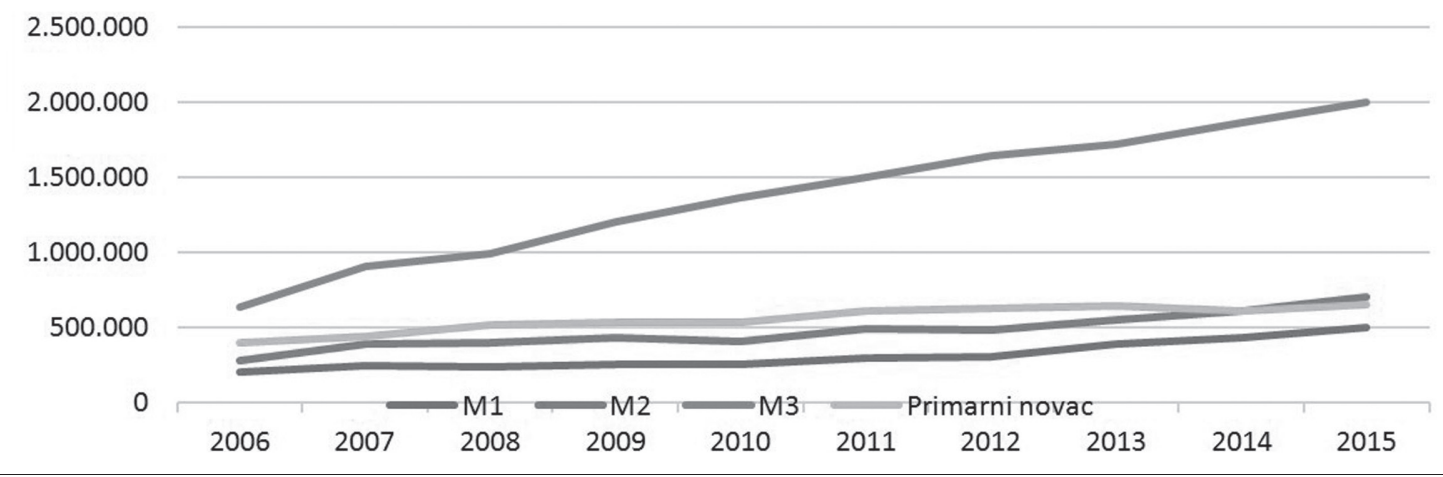

Grafikon 4. Brzina opticaja novca

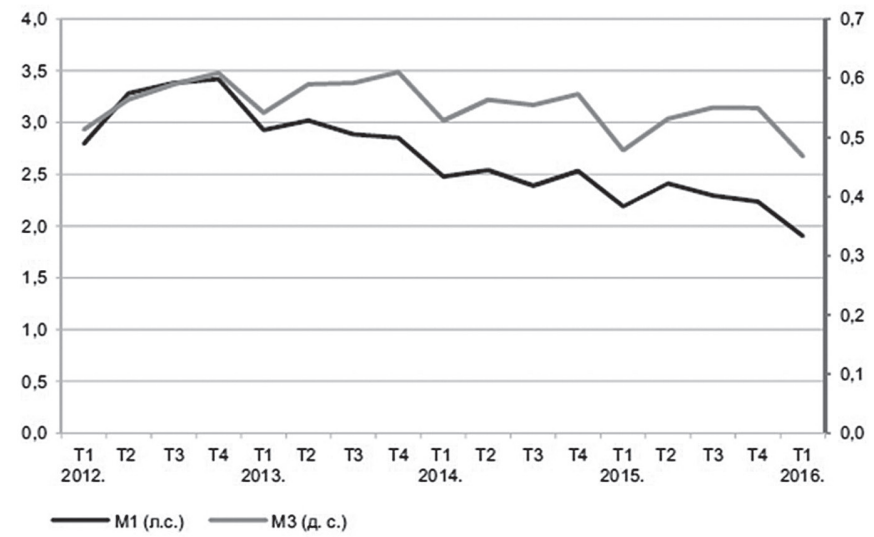


U radu je prikazano koji faktori utiču na brzinu opticaja novca, kako se gledalo nekada i danas u savremenim uslovima. Brzina opticaja novca je veoma specifična i nije je lako obrazložiti, jer na nju utiču brojni faktori do kojih se dolazi na osnovu ekonometrijskih istraživanja. Možemo zaključiti da brzina novca poslednjih godina opada, jer je novčana masa veća, pa je samim tim više vremena potrebno da bi se taj novac "obrnuo".

Kamatne stope NBS su na najnižem nivou i takav trend bi trebalo da se nastavi. Snižavanje kamatne stope dovodi do povećanja investicija (I), odnosno do povećanja dohotka (Y). Takođe, pozitivno je što se vraća poverenje u domaću valutu i štednju u dinarima koja se postepeno povećava. Privreda Srbije je visoko uvozno zavisna. Zbog toga u Srbiji postoji visok stepen korelacije između deviznog kursa i cena. Pored nezavisnog priliva kapitala iz inostranstva, na devizni kurs su uticali i prilivi koji su dolazili sa ciljem plasiranja repo plasmana kod NBS, čime je NBS indirektno (svojim kamatnim stopama) uticala na kurs koji se formirao bez direktnih investicija. Fluktuirajući devizni kurs, koji se primenjuje u Srbiji, može imati negativne posledice na zemlje u tranziciji koje imaju nisku konkurentnost i nedovoljno razvijena finansijska tržišta. Kada je reč o elektronskom novcu, on se danas nalazi u monetarnom sistemu koji se zasniva na papirnom novcu. U cilju njegove dalje primene, neophodno je učiniti ga sredstvom koje će odgovarati potrebama korisnika, kao papirni novac. Među pomenutim efektima na koje deluje elektronski novac, najznačajniji je efekat brzine opticaja novca. Može se zaključiti da će uvođenje e-novca u monetarni sistem dovesti do komplikacija u vođenju monetarne politike od strane centralne banke.

\section{LITERATURA}

Friedman, B. (1999). The Future of Monetary Policy. International Finance, November 1999.

Hadžić, M., \& Barjaktarović, L. (2015). Monetarna ekonomija. Beograd: Univerzitet Singidunum.

Narodna banka Srbije. (2016). Statistički bilten Jul. Preuzeto 06.09.2016. sa http://www.nbs.rs/internet/cirilica/90/sb.html

Sedlarević, L., Furtula, S., \& Tomić, N. (2015). Potencijalni efekti elektronskog novca na monetarnu politiku. Teme, 39(4), 1235-1255.

Wicksell, K. (1965). Interest and prices. New York: Augustus M. Kelley.

\section{VELOCITY FACTORS OF MONEY IN CIRCULATION}

\begin{abstract}
:
This paper deals with the velocity of money in circulation, and makes a comparison between the present and past time practices. In order to show the velocity of money in circulation in the past, we relied on economic theories. Furthermore, we also included the factors that affect the velocity of money in circulation. In addition, the paper will show how electronic money influenced monetary aggregates and the velocity of money in circulation, the changes it brought in the implementation of monetary policy, and will also focus on the downsides of electronic money. The practical part of the paper covers several years prior to the economic crisis and the period of the economic crisis itself, which took place in 2008, and shows how changes in conditions affected the velocity of money in circulation.
\end{abstract}

\section{Keywords:}

electronic money, economic crisis, monetary aggregates, monetary policy, economic theories. 